\title{
THE ROLE OF INTONATION IN THE MANIFISTATION OF WILL IN COURTROOM DISCOURSE
}

\section{Savchuk H. V.}

\section{INTRODUCTION}

The modern stage of linguistics development is characterized by a particular interest in the study of problems of speech communication in various spheres of activity, because it is in socializing that many aspects of human social existence are reflected. The origins and functioning of the language are related to the need for communication, which gives grounds to study the correlation of informative and formal factors in the use of language.

Any act of communication is inherently characterized by intentionality and purposefulness, the desire to exert influence upon the interlocutor and to form certain opinions and beliefs in him. The studies into techniques of linguistic manipulation haven't been the subject of a thorough investigation in an institutional setting yet. Courtroom discourse is one of the most promising and interesting types of institutional discourse for studying.

The understanding of courtroom communication from the point of view of the theory of speech genres, which is actively developing today, opens up new possibilities for revealing the laws of institutional communication. It is the theory of speech genres that allows you to analyze speech communication from a sociological perspective, which is consistent with the study of discourse as a socially significant phenomenon.

Courtroom discourse is a peculiar model of interaction of its participants, where the category of inducement is one of the stylistic features that constitute it, and the highest position for the use of varieties of will among all professional participants of the court audience belongs to the judge, who, addressing to the defendant, the plaintiff, the lawyer, the prosecutor, acts as a court of justice and is obliged to observe the procedure of arranging court proceedings, without allowing violations of public order during the hearing of any court case.

A comprehensive study of the peculiarities of the modality of inducement in the speech of professional participants in the litigation 
gives an opportunity to trace the significance of inducement in the courtroom discourse and to make some contribution to the overall picture of the linguistic description of the language specificity of the most commonly used modal meanings of the functional and semantic field of volition.

With regard to the peculiarities of courtroom discourse, it should be noted that its illocutionary structure expresses the speech intention of the addresser to influence the recipient of information by changing his mental objective picture of the world, and the system of will has a complex nature, which is manifested in the presence of mechanisms that ensure the functioning of directives in courtroom discourse.

Courtroom discourse is a complex phenomenon, and its study must be focused both on vocabulary, syntax, and intonation, which plays an important role in making contact with the audience, attracting its attention, emphasizing the importance of a particular expression, in order to generate the hearer's curiosity to the reported information and influence him.

\section{Intonation as a means of influence and speech contact}

Linguistics and its allied disciplines are increasingly focused on the study of various aspects of human discursive activity. So phonetics and phonology have a close link with modern trends in the study of language functioning and human communication ${ }^{1}$. Segmental and suprasegmental phenomena, registered in different types of discourse, are among the priorities of the study of phoneticians worldwide. The experimental phonetic data obtained during such studies make it easier to solve the major issues of applied nature in medicine, law, forensic linguistics, artificial intelligence, and advanced technologies ${ }^{2}$.

Studying the discourse of the judicial proceedings with its extralinguistic factors, some scholars note the fact that the intensity and content of the court speech, its expressive features are provided not only by the diversity of the vocabulary and the skill of verbal expression, but also by its intonation flexibility and expressiveness. A comprehensive study into the intonation of vivid oral courtroom speech, the identification of its peculiarities, functions has long been the focus of many linguists,

\footnotetext{
${ }^{1}$ Baghmut A. I., Brovchenko T. A., Borysjuk I. V., Olijnyk Gh. P. (1994) Intonatsiina vyraznist zvukovoho movlennia zasobiv masovoi informatsii [Intonation expressiveness of the audio speech of the media]. Kyiv: Naukova dumka. (in Ukrainian)

${ }^{2}$ Miller N. E. (2003) Prosodicheskie kharakteristiki argumentativnykh dialogicheskikh edinstv, realizuyushchikh funktsiyu ubezhdeniya [Prosodic characteristics of argumentative dialogic unities realizing the function of persuasion]. Zapysky z romano-hermanskoi filolohii, vol. 13, pp. 134-141.
} 
such as N. M. Ivakina, N. V. Kozhedub and others ${ }^{3}{ }^{4}$. In general, intonation was of interest to theorists of elocution in ancient times. The orator had to be able to speak clearly, distinctly so that everyone understood what he was talking about. Besides, the public speaker had to influence both the mind and the feelings of the hearers, to be able to gain their sympathy, to win over to his side, to provoke the reaction he needed. To do this, one had to know how to do it, what language means to use. That is why the speakers of Ancient Greece and Rome, laying the foundations of oratory, wrote about intonation ${ }^{5}$.

In their works, which have come to us, melody is described, and determined its difference from the musical one; rhythm, tempo, pauses are characterized; the importance of dividing the flow of speech into significant parts is spoken about. We can really say that intonation began to be interested in the time of the legendary Romulus ${ }^{6}$.

It should be noted that intonation plays an important role in the structure of language of courtroom interaction and performs various functions:

- by means of intonation, the speech flow is divided into relatively independent sense-groups (syntagms), a sentence fragmentation is provided in coherent speech, the subordinate and principal clauses are separated into independent sense-groups in complex sentences, one or more adjacent elements are separated (e.g. the subject, expressed by the noun, adverbial groups, forms of address, objects, etc. $)^{7}$;

- intonation organizes various syntactic constructions and types of sentences;

- the stylistic function of intonation also plays an important role in the formation of the text, since any judicial text is pronounced in a particular style (official, scientific, journalistic) or contains features of all three above mentioned styles. Linguists, in turn, find out how the

\footnotetext{
${ }^{3}$ Ivakina N. N. (2000) Osnovy sudebnogo krasnorechiya (ritorika dlya yuristov) [The Basics of Judicial Eloquence (Rhetoric for Lawyers)]. Moscow: Yurist. (in Russian)

${ }^{4}$ Kozhedub, N.V. (2009) Prosodicheskaya realizatsiya ubezhdeniya kak odnogo iz vidov rechevogo vozdeystviya v sudebnoy rechi: eksperimental'no-foneticheskoye issledovaniye na materiale britanskogo varianta angliyskogo yazyka [Prosodic realization of persuasion as one of the types of speech influence in courtroom speech: an experimental-phonetic study based on the material of British English] (PhD thesis), Nizhny Novgorod: Nizhny Novgorod N. A Dobrolyubov State Linguistic University.

5 Gubayeva T. V. (2003) Yazyk i pravo. Iskusstvo vladeniya slovom v professional'noy yuridicheskoy deyatel'nosti [Language and law. The art of verbal skill in professional legal practice]. Moscow: Norma. (in Russian)

${ }^{6}$ Abramovych S. D., Moldovan V.V., Chykarkova M. Yu. (2002) Rytoryka zahalna ta sudova [General and judicial rhetoric]. Kyiv: Yurinkom Inter. (in Ukrainian)

${ }^{7}$ Borysiuk I. V. (1990) Formy i funktsii intonatsii ukrainskoho spontannoho movlennia [Forms and functions of intonation of Ukrainian spontaneous speech]. Kyiv: Naukova dumka. (in Ukrainian)
} 
intonation changes according to style and genre. In the studies into the stylistic features of courtroom discourse, particular attention is paid to the intellectual meaning of intonation, since it allows the speaker to emphasize in the utterance what is most important at the moment of speaking;

- intonation is involved in expressing the opinion, feeling and will of the forensic orator.

As we can see, intonation performs a variety of functions in courtroom speech: communicative, integrative and actual division of utterances, optative, emotionally expressive, inducing, etc. It should be added that a special place in the modern courtroom discourse is given to the inducement function of intonation, when it expresses volition actions: order, command, prohibition, request, warning, threat, pleading, reproach, permission, instruction, protest, persuasion, consent, recommendation. In this regard, there are three communicative types of influence on the will and actions of hearers: 1) inducement (order, request, and requirement); 2) order to cease (ban, threat, reprimand); 3) beliefs (suggestion, advice, instruction) ${ }^{8}$. The leading role of intonation in the expression of volition has been emphasized in the works of famous linguists. So V. V. Vinogradov wrote that intonation by itself can turn any word into an expression of an order ${ }^{9}$.

In linguistics, intonation is considered to be as one of the obligatory means of sentence formation along with lexical or grammatical linguistic means. In favour of the fact that intonation is a special means of expression of will, relatively autonomous from lexical and grammatical language means, weighs heavily the ability of intonation means to change the communicative goal-setting of the sentence, while maintaining its lexical and grammatical structure.

The current stage in the development of linguistics is characterized by a particular interest in the problems of speech communication and language functioning in the judicial sphere. The intonation of inducement is peculiar to the speech of judges, lawyers, prosecutors, because most of their utterances are of an impellent nature. Nowadays, it is impossible for forensic orators not to be guided by directive methods, especially when it concerns the oral form of communication, in the process of which the

\footnotetext{
${ }^{8}$ Miasoiedova S. V. (2001) Katehoriia sponukannia i yii vyrazhennia v nepriamykh vyslovlenniakh suchasnoi ukrainskoi movy [The category of urge and its expression in the indirect expressions of modern Ukrainian]. Extended abstract of PhD Thesis. Kharkiv.

${ }^{9}$ Vinogradov V. V. (1996) Russkiy yazyk. Grammaticheskoe uchenie o slove [Russian language. Grammar teaching of the word]. Moscow: Vysshaya shkola. (in Russian)
} 
opinions and interests of groups of people are brought together, the general principles of interaction and specific plans of cooperation are worked out, the ways out of conflict situations are found. The directive form of communication is used to express orders, recommendations, suggestions, requirements, requests of the speaker, etc. ${ }^{10}$; at the same time in oral courtroom speech, for example, the difference between the order and the request and the different shades of meanings of orders and requests, which often have various emotional-modal colouring, can be traced precisely in the addresser's intonation of pronouncing of a particular utterance expressing inducement.

In addition, during inducing dialogic communication in court, the participants enter into special relationships, which are characterized by a measure of the dependence of one of them on the will of the other. In this case, the speaker's intention can be realized at different stages of communication.

It should also be noted the role of intonation in the exercise of the influence function, in creating a certain style of oral communication in the litigation $^{11}$. This or that style arises as a result of the presence of signals that set the interlocutor to receive the message and enhance the degree of influence on him to carry out a specific action. In this case, the style of communication is determined by the nature of relations between the participants in interaction, and also significantly influences the success of social contact.

As for intonation, it also plays an important role in the communicative situation, in establishing and maintaining contact, on the one hand, the judge checks the communication channel through contact language means, and on the other hand, the interlocutor (defendant, lawyer, prosecutor) confirms that speech is clear (unclear) to him and he agrees (disagrees) to continue communication. In any case, when he or she uses inducing remarks in the course of interaction, he or she expresses his / her subjective attitude to the reported fact and exerts a certain influence on the hearers in order to induce one person or the whole group to perform one or another action.

Various forms of inducement, fixed in the speech of professional lawyers, act as the significant words and grammatical forms and form a

10 Berezhan L. V. (1997) Katehoriia sponukalnosti v suchasnii ukrainskii movi [The category of inducement in modern Ukrainian]. Extended abstract of PhD Thesis. Ivano-Frankivsk: Carpathian V. Stefanyk State University.

${ }^{11}$ Wennerstrom, A. K. (2001) The Music of Everyday Speech: Prosody and Discourse Analysis. Oxford University Press. 
special kind of modality, i.e., the inducement, which is marked by the various degree of inducement relations, directly in which the intonation of inducement is involved.

At the same time, intonation is involved in the transfer of sense relations, which carry additional information of emotional and evaluative character, realized in the form of various connotations, as well as in the explicit expression of modal meanings, giving special influence sense to the utterances of the professional participants of the courtroom audience.

As mentioned above, intonation plays an important role in shaping the utterances of judges, lawyers, prosecutors, exercising the function of influencing differently in each remark of the orator depending on the nature of influence on the will of the hearer, and acts as a means of contact, while enhancing the pragmatic focus of professional participants' utterances of judicial proceedings.

Thus, in the current courtroom discourse, a wide range of intonation means is used to facilitate the contact of the forensic orator with the audience, while gaining their affection and influencing emotions, showing the focus of the lawyers' utterances on the interlocutor, defining the nature of communication and relations between the communicants.

\section{Intonation peculiarities of inducement utterances in courtroom discourse}

Observing the American and Ukrainian judges in their legal and administrative activities in court, we have noticed that there are many situations in which they have to use an imperative that is entirely justified by aim and the ethics of interaction. Typically, the use of directives (requirements, advice, requests, etc.) by judges in dealing with litigants is meant for encouraging an action, to gain some control over the addressee's behaviour and attitudes. At the same time, in various situations and social activity, it is the category of inducement that allows with great conviction and clarity to trace and analyze the mechanism of interaction of judges with participants of communication.

On the basis of the conducted research of American and Ukrainian judges' speech, we were able to describe the model of their speech communication in a causal situation.

1. In a situation of inducement, the basis of the verbal behaviour of the judge and the addressee is the awareness of a state of affairs that requires change, of which the judge also informs the addressee, inviting him to become the executor of the necessary action. It is the distribution 
of communicative roles and the focus of the illocutionary act that belongs to the judge who dictates and directs the addressee's behaviour. In such a situation, the participants' verbal behaviour can be characterized as unidirectional, i.e., focused on carrying out the necessary action. For the most part, the addressee's interests are not taken into account; as a rule, the addresser (judge) dominates over the addressee of the causation.

2. The social distance is the most important feature in characterizing the situation of the inducement between the judge and the addressee of the causation.

3. Interaction between communicants in the canonical situation of inducement during the hearing is usually dialogic, but there are cases of unexpected conflict situations that cause the transformation of the type of interaction from dialogic to the discussion involving more than two people.

4. Depending on the function and content of the judge's directive utterance, his interaction with the addressee can be described as official, characterized by a regulated institutional framework.

5. The presence of the emotional colouring of the judge's inducement utterance the auditors described as positive in $80 \%$ of the total number of inducement phrases, in $20 \%$ of the cases the emotional colouring was characterised as negative. The negative colouring of the inducement utterance of the judges was caused by the violations of the discipline or the rules of trial by some of its participants (plaintiff, defendant, and lawyer).

6. At the time of the courtroom activity, the authoritarianism of the judge is clearly observed in interaction with the addressee (clear speech, brief orders and instructions, striving for domination in order to compel observance of or compliance with (a law, rule, or obligation).

7. The use of a wide range of meanings of the functional and semantic field of volition (requirement, requirement + warning, requirement + threat, advice, suggestion, request, etc.) to enhance the influence on the addressee.

Owing to the study of numerous inducement utterances (about 500 phrases), the following types of influence on the will and actions of participants in the trial were identified in the speech of American and Ukrainian judges: 1 ) requirement; 2 ) requirement + warning; 3) demand + threat; 4) advice; 5) suggestion; 6) request.

As a result of doing various types of analyses (semantic, auditory, instrumental), as well as making systematic observations on the 
peculiarities of the types of inducement in courtroom discourse, it should be noted that the judge compared with other forensic orators dominates in using the semantic shades of directive modality. He acts as a legislator, and is empowered with administrative authority to provide explanatory guidance when undertaking judicial activity in the search for the truth and the establishment of the substantial facts to the court passing a just sentence that will determine the fate of the defendant.

In general, the scheme of interaction of a judge in a causal situation is as follows:

- the judge notifies the addressee of any situation that requires immediate change and implies the urgency of exercising a particular type of will;

- a peculiar feature of the inducement situation, in which the judge and recipient of information participate, is the presence of a social distance that gives the relationship a formal character;

- oral communication between the judge and the participants of judicial sitting

in the canonical situation of inducement is dialogic. As soon as there are disputes in the process of hearing the case, the dialogue becomes polylogue;

- the spoken interaction of the judge with the addressee in a causal situation can be described as official, regulated and institutional;

- emotional colouring of inducement utterances of the judges is mostly positive (advice, suggestion, request), but there are also cases of negative emotional colouring, mainly in the implementation of requirement, requirement + threat, requirement + warning;

- in the course of spoken interaction of the judge with the addressee, his dominating role (authoritarian style of communication) is traced in any causal situation, as well as his use of a wide range of shades of directive modality: requirement, requirement + warning, requirement + threat, advice, suggestion, request.

It should be noted that professional trial participants, when resorting to the use of various types of inducement, try not only to provide information but also to influence the addressee in some way, that's why special attention was paid to the use and functioning of linguistic units in the study of the language of judges.

The analysis of directive modality in the courtroom discourse gives grounds to assert that a significant place in the expression of the modal shades of the inducement belongs to such a syntactic means as intonation, which plays an important role in conveying utterance meaning. 
Research on inducement judges' remarks has shown that in the process of communication they are characterized by acquiring different modal-emotional meanings, which make certain changes in the semantics of expression and its colouring. However, during the systematic analysis of intonation structures of semantic shades of volitional modality, there was no a clear dependence of intonation shaping on the type of inducement, and due to the occurrence of subjective, modal and emotional shades of attitude, the complexity of the modal semantics was found out.

Thus, the experimental material made it possible to conclude that differentiations of the investigated types of directive modality are facilitated by the modal-emotional meanings used with them, which have their own intonation pattern. The validity of the made assumption was confirmed by the results of a statistical study of modal-emotional meanings and the specific types of will expression that are often associated with them. This, in turn, gave rise to the classification of modal-emotional connotations involved in the implementation of various types of inducement into three groups: 1) the meanings correlating with the directive utterances of judges are the bulk of the modal-emotional connotations of the first group (85-100\%); 2) modal-emotional connotations, which are the most common in judges' recommendations and appeals (98\%), constitute the second group;

3) the third group included modal-emotional connotations, the use of which was observed both in the implementation of directive utterances (25-75\%), and remarks of the recommendation (50\%) and appeal (50\%) zones.

Investigating the prosodic organization of voluntative phrases expressing modal-emotional shades of the utterance, we can note that the most common connotations of the requirement were rigidity, reproach, disapproval, objection; when actualizing the meanings of the requirement + warning there were disapproval, condemnation, tension, denial; threat, protest, condemnation were characteristic of requirement + threat; some bits of advice and suggestions connoted guidance, edification, explanation, support; politeness, unobtrusiveness were typical of the request.

On the basis of the auditory and instrumental analyses of intonation characteristics of varieties of directive modality in Ukrainian and American speech of judges the following general features were identified.

1. It is peculiar for the requirement as follows: an extremely descending movement of the head speech melody; the types of the heads 
are the Low Level Head, the Low Descending Sliding Head, the Low Descending Scandent Head, the Low Ascending Sliding Head; the distribution of such terminal tones as the Low Rise-Fall, the Mid-Fall or High Fall and Low Rise; the fundamental frequency maximum averages are mainly in the terminal part; an apparent increase in loudness; the peak of the intensity is in the head; the use of normal (syntagmatic) and logical types of sentence-stress; the occurrence of warning, intonation-syntactic pauses; categorical colouring of timbre (see Fig. 1).

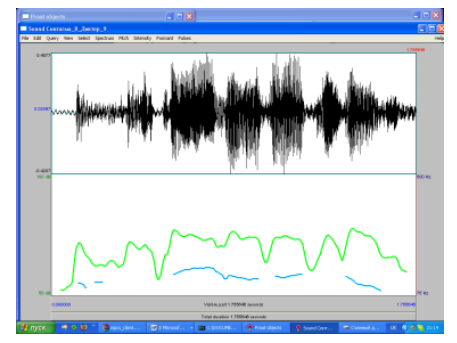

Fig. 1. The intonogram of requirement "'Describe your" actions"

2. In the requirement + warning downwards, static, and upwards movements of the speech melody are observed in the head; the distribution of the Low Level Head, Low Descending Sliding Head; the prevalence of the Low Fall and Low, Mid, High Rise-Fall; the peak of the intensity and the highest values of the fundamental frequency's interval are in the terminal part; increased loudness; the use of normal (syntagmatic) and logical types of sentence-stress; warning, punctuation, intonation-syntactic pauses are widespread; severe colouring of timbre (see Fig. 2).

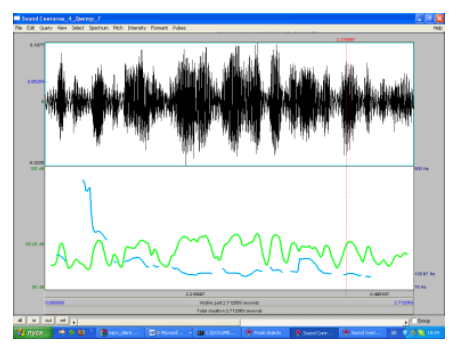

Fig. 2. The intonogram of requirement + warning „The ' truth of any 'testimony here will be de'cided by the $\backslash$ jury”

3. In the requirement + threat there is an overwhelming predominance of the descending movement of the head melody; the occurence of the Low Descending Sliding Head, Low Level Head; the 
extensive use of the Low Rise-Fall is peculiar to the terminal part; the peak of the fundamental frequency and the highest frequency interval's values are in the head; the localization of the maximum intensity values is in the head; the use of the normal sentence-stress; the distribution of warning and intonation-syntactic pauses; a fast rate of pronunciation; harsh and categorical colouring of timbre (see Fig. 3).

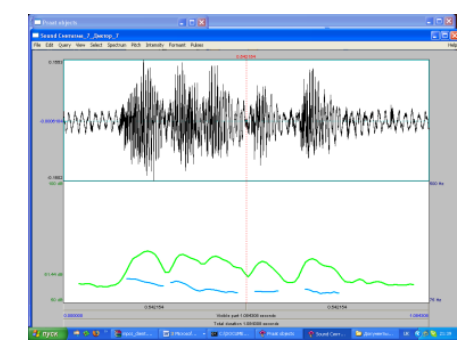

Fig. 3. The intonogram of requirement + threat "'You will re/gret it"

4. In the advice there are commonly downward and upward movements of the melody observed in the head; the prevailing types of the heads are the Low Ascending Sliding Head and the Low Ascending Stepping Head; cases of occurrence of the Low Descending Scandent and Level Heads; the most characteristic terminal tones are the Low Rise, the Low Fall-Rise; the peak of the fundamental frequency and the highest values of the fundamental frequency's interval are in the head; moderate loudness; distribution of the normal type of sentence-stress; hezitation and intonation-syntactic pauses are employed; soft, friendly colouring of timbre (see Fig. 4).

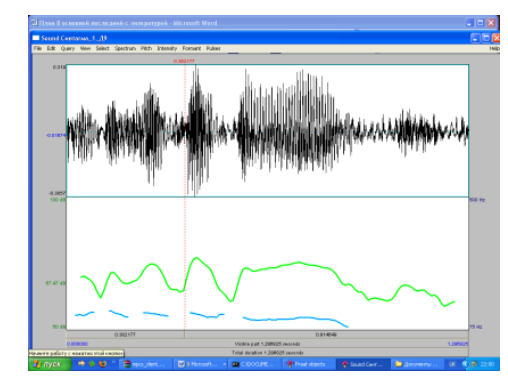

Fig. 4. The intonogram of the advice "You' better have 'something 'new, Counselor"

5. In the suggestion there is a predominance of downward and the occurance of upward directions of the head melody; the Low Ascending Stepping Head is commonly used, but the results show that the Low Ascending Sliding Head is seldom employed; the most common terminal 
tone is the Low Fall-Rise; the average maximum values of the fundamental frequency and the intensity peak are localized in the head; moderate loudness; the characteristic use of the normal sentence-stress; the occurrence of hezitation and intonation-syntactic pauses; soft, sincere colouring of timbre (see Fig. 5).

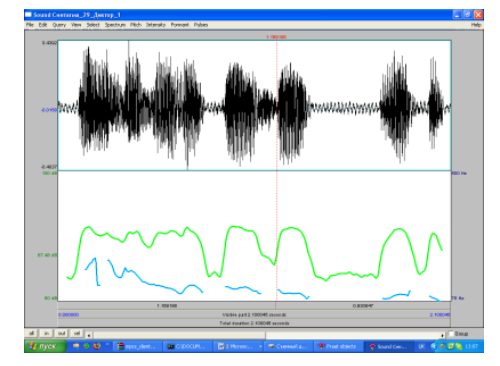

Fig. 5. The intonogram of the suggestion “Но або знай'dіть 'іниий“'вихід”

6. In the request the upwards melodic movement of the head is observed; the use of the Low, Medium Ascending Stepping Head and the Low, Medium Ascending Sliding Head; the distribution of the Low Fall, the Low Rise, and the Low Fall-Rise terminal tones; the maximum values of the fundamental frequency and the highest frequency interval values are localized in the head; moderate loudness; the intensity peak is in the head; lowered tempo; the characteristic use of the normal sentence-stress; the occurrence of punctuation, intonation-syntactic pauses; polite, soft colouring of timbre (see Fig. 6).

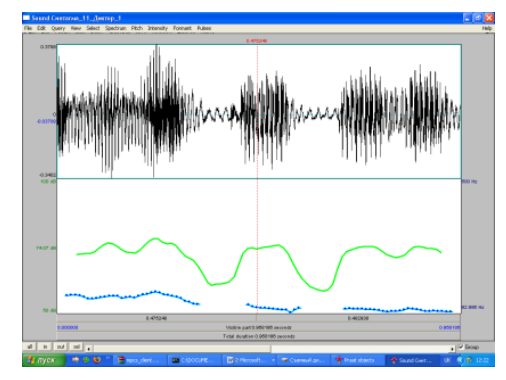

Fig. 6. The intonogram of the request «Будь \ласка, відповідачу»

The results obtained during the experimental-phonetic analysis of the intonation structure of the inducement phrases in the speech of Ukrainian and American judges, show that intonation acts as one of the main means of differentiation of modal meanings of the functional and semantic field volition and is a unity of a number of interdependent communication components. 
All the considered components of intonation (melodic, dynamic, temporal), which ensure the expression of the modal meanings of functional and semantic field volition in the speech of judges, both interact and influence each other.

The existence of interaction by type of complementarity is traced between such components of intonation as dynamic and temporal when American judges suggest, advise and request. Thus, a significant increase in the intensity of the suggestion is characterized by an acceleration of the rate of pronunciation of the aforementioned modal meaning, a decrease in the intensity of the request and advice pronouncing leads to a slower pace of implementation of the request or gives a measured tonal characteristic to the advice. With regard to the pronunciation of varieties of the requirement and the actual requirement, it should be noted that the interaction between the temporal and dynamic components of intonation by type of complementarity is not expressed, that is, the increase in the intensity of pronouncing by the judges of the above types of volition does not cause changes in such an intonation component as tempo.

Thus, in the Ukrainian courtroom discourse, namely in the speech of the judges, the nature of the interaction between the dynamic and temporal components is expressed a little stronger in the implementation of the requirement + warning, requirement + threat at an accelerated tempo with a marked increase in their quantitative dynamic values. Variation of intensity values downwards leads to the implementation of the advice at an average tempo and suggestion and request at a slow tempo. However, at the same time, the tendency of the interaction of temporal and dynamic components was found to be weak when expressing the meanings of the requirement. It is established that increasing the quantitative values of the dynamic parameters of the abovestated type of volition does not cause any changes in the acceleration of tempo.

It is interesting to note that in the speech of judges, the temporal component of the inducement utterances changes significantly due to the sphere and style of speech. The courtroom discourse manifests, first of all, the features of official, journalistic and scientific styles that influence the temporal structure of the inducement utterences of judges.

As a result of observing the nature of the tempo, the realization of the most frequent semantic shades of the directive modality in the speech of American and Ukrainian judges has detected a number of factors that influence the acceleration or deceleration of the speech tempo. 
Therefore, the tendency to accelerate the rate of pronouncing types of volition by American and Ukrainian judges may be caused by the following factors:

- the nature of the case being heard in the courtroom;

- the choice of a judge tactics of interaction with participants in the trial;

- alternation of journalistic style with all its peculiarities (clarity, brevity), official (objectivity, informativeness), as well as scientific (accuracy, logic of presentation, the speaker's desire is accessible, quick and clear to express a point of view and attract the attention of the audience);

- the emotional state of the judge with the maximum degree of tension of positive (negative) emotions or volitional efforts;

- the rhythmic structure of the inducement phrases;

- the degree of formality;

- the wish of the judge to convey the important information faster and encourage the addressee to take the necessary action;

- demonstration of the hierarchy of relations of communicants (judge - lawyer, judge - prosecutor, judge - defendant);

- the desire of judges to exercise an effective regulatory function in the course of the trial;

- the individual characteristics of the judge, which characterize his mental activity.

The slow or moderate tempo of types of inducement in the judges' speech may be related to:

- exerting influence on the hearer by emphasizing the expediency of performing the necessary action and focusing on certain, most important aspects of the case under discussion;

- the judge has a negative or positive assessment regarding the situation that occurs in the courtroom;

- style of speech that combines informativeness, expressiveness, influence (scientific, official, journalistic);

- maintain communication in accordance with the assigned social role and granted administrative and legal powers, while emphasizing the strength and advantage of the position;

- the nature of the situation in which particular issues of the case are being discussed, subject to certain rules and formalities; 
- the choice of a communicative strategy with interlocutors (lawyers, prosecutors, administrative employees, plaintiffs, defendants, etc.);

- rhythmic organization of judges’ utterances;

- type of temperament.

In the intonation pattern of the semantic shades of the directive modality in both Ukrainian and English judges' speech, there is a significant similarity in the nature of the movement of the intensity curves and the fundamental frequency. This fact testifies to the unidirectionality of the action, as well as to the interrelation of the two aforementioned components of intonation when conveying the impellent statements of "justice spokesmen".

The data of experimental-phonetic study of the intonation characteristics of the phrases of the functional and semantic field of volition have provided an opportunity to analyze the main features of the change of the melodic, dynamic, temporal components of intonation taking into account linguistic and extralinguistic factors, as well as to systematize the conditions of varying elements of prosody in the realization of semantic shades of directive modality in courtroom discourse. In all of the above modal meanings of the functional and semantic field of volition in the speech of judges, intonation plays a leading role in the implementation of the function of influence on the addressee (defendant, plaintiff), regulates the process of communication in the courtroom, creates a certain psychological climate, gives different shades of meaning to the verbal realization of judges and helps to identify types of volition.

\section{CONCLUSIONS}

In the study of courtroom discourse, the leading role of intonation is identified, which is manifested not only in conveying meaningful and emotional differences of utterances, in making contact and showing the status, mood of litigants, their attitude to the subject under discussion or to each other, and as well as in influencing the audience and regulating the communicative behavior of its participants.

The use of directives in the speech of Themis representatives is resulted from the conditions of communication, professional activity, the purpose of communication and, of course, the nature of the judicial sphere. During the court hearings the most frequent types of inducement as requirement, requirement + warning, requirement + threat, advice, suggestion, request were revealed in the speech of Ukrainian and 
American judges. Within the semantic meaning of the directive modality of the requirement, the overlays of emotional and modal meanings of threat and warning were often observed, which was explained both in the English and Ukrainian judicial discourses by the following factors: 1) the communicative situation, the circumstances to which the speech was sensitive while forming the abovementioned modal meanings of the functional and semantic field of volition; 2) the desire of the judge to emphasize the dominant position, high authority and the addressee status by means of categorical statements.

As the experimental-phonetic study has shown, the functioning of intonation means of expressing a modality of inducement in the speech of American and Ukrainian judges is influenced by: 1) the purpose and tasks of the message; 2) style of speech; 3) communication scenario; 4) emotional and expressive coloring of the situation; 5) basic (acceptable in this community) and personal values in the form of ideological, moral and other assessments of the world around us; 6) strategies and tactics for achieving the desired effect; 7) individual features of speech; 8) the occurrence of modal, emotional connotations; 9) national cultural stereotypes (patterns of intellectual operations); 10) the official nature of the relations between the communicants; 11) the social verbal environment to which the communicant belongs; 12) peculiarities of the courtroom sphere of communication.

\section{SUMMARY}

The article deals with the peculiarities of the intonation of inducement, which plays an important role in the judicial sphere (conflict settlement, ensuring the observance of legal norms and forms of public behavior in the courtroom, etc.).

The category of inducement, which is a significant feature of communication in court, is defined. The semantic varieties of directive modality in the speech of professional participants (judges) in the trial are characterized and the intonation means of its expression are described. It has been determined that the modality of inducement is mainly realized through imperative situations in courtroom discourse that expect the obligatory performance of an action. It is found out that the central place among all the court speakers regarding the use of semantic shades of directive modality belongs to the judge endowed with administrative powers. 
The results of the intonation analysis of inducing judge's phrases (requirement, advice, request) and the emotional-modal connotations they have showed that the intonation means carry a functional yield in order to express the most accurate modal-evaluative meanings of the functionalsemantic field of volition, and each of the inducing phrases has a certain communicative meaning with a different type of correlation of differential means of various levels of speech.

It is investigated that professional groups (judges) act as speakers of the language, which has its specificity in the intonation pattern of various shades of imperative modality, the nature of which depends on the real conditions, where different mechanisms of language interaction and environment operate.

\section{REFERENCES}

1. Baghmut A. I., Brovchenko T. A., Borysjuk I. V., Olijnyk Gh. P. (1994) Intonatsiina vyraznist zvukovoho movlennia zasobiv masovoi informatsii [Intonation expressiveness of the audio speech of the media]. Kyiv: Naukova dumka. (in Ukrainian)

2. Miller N. E. (2003) Prosodicheskie kharakteristiki argumentativnykh dialogicheskikh edinstv, realizuyushchikh funktsiyu ubezhdeniya [Prosodic characteristics of argumentative dialogic unities realizing the function of persuasion]. Zapysky z romano-hermanskoi filolohii, vol. 13, pp. 134-141.

3. Ivakina N. N. (2000) Osnovy sudebnogo krasnorechiya (ritorika dlya yuristov) [The Basics of Judicial Eloquence (Rhetoric for Lawyers)]. Moscow: Yurist. (in Russian)

4. Kozhedub, N.V. (2009) Prosodicheskaya realizatsiya ubezhdeniya kak odnogo iz vidov rechevogo vozdeystviya $\mathrm{V}$ sudebnoy rechi: eksperimental'no-foneticheskoye issledovaniye na materiale britanskogo varianta angliyskogo yazyka [Prosodic realization of persuasion as one of the types of speech influence in courtroom speech: an experimentalphonetic study based on the material of British English] (PhD thesis), Nizhny Novgorod: Nizhny Novgorod N. A Dobrolyubov State Linguistic University.

5. Gubayeva T. V. (2003) Yazyk i pravo. Iskusstvo vladeniya slovom $\mathrm{v}$ professional'noy yuridicheskoy deyatel'nosti [Language and law. The art of verbal skill in professional legal practice]. Moscow: Norma. (in Russian) 
6. Abramovych S. D., Moldovan V.V., Chykarkova M. Yu. (2002) Rytoryka zahalna ta sudova [General and judicial rhetoric]. Kyiv: Yurinkom Inter. (in Ukrainian)

7. Borysiuk I. V. (1990) Formy i funktsii intonatsii ukrainskoho spontannoho movlennia [Forms and functions of intonation of Ukrainian spontaneous speech]. Kyiv: Naukova dumka. (in Ukrainian)

8. Miasoiedova S. V. (2001) Katehoriia sponukannia i yii vyrazhennia $\mathrm{v}$ nepriamykh vyslovlenniakh suchasnoi ukrainskoi movy [The category of urge and its expression in the indirect expressions of modern Ukrainian]. Extended abstract of PhD Thesis. Kharkiv.

9.Berezhan L. V. (1997) Katehoriia sponukalnosti v suchasnii ukrainskii movi [The category of inducement in modern Ukrainian]. Extended abstract of $\mathrm{PhD}$ Thesis. Ivano-Frankivsk: Carpathian V. Stefanyk State University.

10. Wennerstrom, A. K. (2001) The Music of Everyday Speech: Prosody and Discourse Analysis. Oxford University Press.

\section{Information about the author:} Savchuk H. V., PhD in Philology, Associate Professor, Associate Professor at the Department of Translation and Linguistics,

International Humanitarian University 33, Fontanska doroha str., Odesa, 65000, Ukraine ORCID ID: orcid.org/0000-0003-4872-8722 